\title{
The Flipped Pedagogy: Effects on the Grammatical Competence and Writing Skill of Basic Users of English
}

\author{
Mohammadreza Valizadeh \\ Department of Translation and Interpretation (English), Faculty of Humanities, \\ Cappadocia University, Cappadocia, Turkey, mrvalizadeh2015@gmail.com
}

\section{Fatemeh Soltanpour}

English Department, Kar Higher Education Institute, PO Box 1571, Qazvin, Iran, fatemeh.soltanpour@gmail.com

\begin{abstract}
This experimental study, using a pretest-intervention-posttest design, aims to explore the effect of semi-flipped instruction on the grammatical competence and writing skill of basic users of English. These users were also considered to be low achievers among their classmates, based on the opinions of their teachers, the criteria of the institute as well as the Common European Framework of Reference (CEFR) for languages. The participants consisted of 53 Iranian students, who were assigned to two groups: the flipped and non-flipped. Each group received ten sessions of intervention. First, it was investigated whether there was any significant difference between the two groups in terms of their grammatical competence and writing skill. The flipped group significantly outperformed the non-flipped one. Next, it was examined whether the non-flipped intervention caused any significant change in the grammatical competence and writing skill of the non-flipped participants, and significant changes were found. The superiority of the flipped pedagogy can be attributed to the process of actively engaging the students in their learning activity in addition to including various techniques, such as collaborative writing, in-class teacher-learner interaction and negotiation as well as the video screencasting, because it is argued that the essential feature of flipped instruction is how the instructors best utilize in-class-time with the learners.
\end{abstract}

Keywords: basic users of English, EFL, English as a Foreign Language Learners, flipped pedagogy, grammatical competence, writing skill

\section{INTRODUCTION}

Flipped instruction is a newly emerged pedagogical approach (Ekmekci, 2017; Tucker, 2012), corroborated by active learning (Bonnell \& Eison, 1991; Meyers \& Jones, 1993),

Citation: Valizadeh, M., \& Soltanpour, F. (2020). The Flipped Pedagogy: Effects on the Grammatical Competence and Writing Skill of Basic Users of English. International Journal of Instruction, 13(3), 761-776. https://doi.org/10.29333/iji.2020.13351a 
interactional theory and Vygotsky's socio-cultural learning theory (Richards \& Rodgers, 2014). Flipped pedagogy inverts the learning process by reversing the order of typical activities of common teaching practice (Ekmekci, 2017; Tucker, 2012); in flipped teaching, lectures, common in conventional methodology, are removed, yet the needed input materials are given to students through pre-class materials such as books, pamphlets, worksheets, PowerPoint files as well as audio and video recordings. Utilizing technology is not a must, yet the input materials can be integrated or supplemented with technology such as instructional videos (Ekmekci, 2017; Milman, 2012; Tucker, 2012).

The flipped teaching is personalized and student-centered because students take responsibility for their learning by studying and learning the provided materials on their own and at their own pace outside of class time (Basal, 2015; Egbert, Herman, \& Lee, 2015; Milman, 2012; Muldrow, 2013). Then, during the in-class time, the learners interact with their instructor and peers in order to consolidate their knowledge and learn by asking their raised questions and engage more actively and constructively in teacherprepared class activities, including group work and interactive discussion (Baepler, Walker, \& Driessen, 2014; Basal, 2015; Bishop \& Verleger, 2013; Danker, 2015; Davies, Dean, \& Ball, 2013; Egbert et al., 2015; Milman, 2012; Muldrow, 2013; O'Flaherty \& Phillips, 2015), while the instructor's roles will be that of a guide, facilitator and organizer (Basal, 2015; Bishop \& Verleger, 2013; Milman, 2012). Teachers can structure in-class time to optimize their attention to each pupil (Ekmekci, 2017; Muldrow, 2013) and carefully notice their learning (Johnson \& Renner, 2012; Roehl, Reddy, \& Shannon, 2013) that may not be usually possible in conventional nonflipped classrooms due to time constraints (Egbert et al., 2015; Muldrow, 2013).

As for the literature on the efficacy of the flipped instruction, Ekmekci (2017) rightly stated that "studies on the flipped classroom are limited, but studies on flipped language learning classrooms are much more limited." (p. 155) Hung's (2015) study on the effects of flipped instruction on EFL Taiwanese college students revealed that full-flipped and semi-flipped lessons were more beneficial than the traditional ones. The participants also showed positive attitudes towards the flipped learning. Similarly, promising results and positive opinions were found by Lee and Wallace's (2018) recent investigation on the efficacy of the flipped pedagogy on South Korean students' English learning. Concerning the L2 writing skill, few studies which compared the flipped teaching with the traditional ones proved that adopting the flipped approach was more advantageous than the traditional methodology and greatly contributed to improving the learners' writing proficiency (Afrilyasanti, Cahyono, \& Astuti, 2016; Ahmed, 2016; Ekmekci, 2017; Farah, 2014; Leis, Tohei, \& Cooke, 2015; Soltanpour \& Valizadeh, 2018). Nonetheless, Muldrow (2013) stated that flipped instruction does not work in every single community, especially because of contextual differences. Furthermore, Soltanpour and Valizadeh (2018) claimed that the L2 learners' proficiency level may affect the outcomes of flipped pedagogy. Consequently, it can be stated that although the mentioned research indicated promising results, reaching a valid conclusion on the effectiveness of flipped pedagogy entails more investigation because the previous studies were conducted in different contexts with various participants. For instance, Farah (2014) explored the effect of flipped teaching on the writing performance of 
twelfth grade female Emirati students at a technical high school during a fifteen-week program. The participants in Leis et al.'s (2015) research were Japanese university students studying various majors. Afrilyasanti et al., (2016) worked with EFL Indonesian students, aged 15 and 16 at a secondary school. Ahmed (2016) investigated the writing skill improvement of female university students in Saudi Arabia. Ekmekci (2017) explored the writing performance of Turkish English Language Teaching (ELT) students. Finally, more recently, Soltanpour and Valizadeh (2018) studied the effectiveness of the flipped approach on the quality of argumentative essays written by Iranian EFL learners at the upper-intermediate proficiency level. In conclusion, it is difficult to generalize from the previously conducted studies, and as Lee and Wallace (2018) correctly stated, "although many educators have recently discussed the positive effects of flipped learning, there is little empirical evidence about whether this approach can actually promote students' English learning." (p. 62)

Concerning the context of the present study, the researchers observed some Iranian students who had a basic command of English; they were basic users of English based on the Common European Framework of Reference for languages (CEFR), yet were considered to be low-achievers according to the criteria of the CEFR and the institute; they lacked grammatical competence and their writing and speaking performance was poor. What made the situation even worse was that giving these learners more practice in the basic academic writing skills was a challenge for the teachers of the institute due to limited class time. As a matter of fact, many EFL teachers of the institute argued that they lack sufficient class time to provide each student with individualized feedback on their English ability.

One more issue that holds true for all Iranian EFL learners is that in Iran (as in many EFL situations), the English language is not used as a means of communication in society but is only taught as a subject in public and private schools as well as language institutes, which makes the English learning process more challenging. Therefore, the Iranian EFL learners have very few opportunities to obtain any significant language input outside the class. Although the EFL learners have been screened through different summative and formative tests, they vary in terms of their English language competence and performance.

In light of the stated context and issues, the researchers of the current study decided to provide the above-mentioned learners with more various language input and feedback via the flipped instruction. However, to find out whether the flipped instruction can be more beneficial than the conventional lecture-based pedagogy, the learners were randomly divided to two groups as the flipped and non-flipped ones. In brief, the following research questions were addressed:

1. Is there any significant difference between the flipped and non-flipped groups in their paragraph writing skill after the treatment?

2. Is there any significant difference between the flipped and non-flipped groups in their grammatical competence after the treatment? 
3. Does the non-flipped intervention cause any significant change in the grammatical competence of the non-flipped participants?

4. Does the non-flipped intervention cause any significant change in the writing skill of the non-flipped participants?

\section{METHOD}

\section{Design}

The study, using pretest-intervention-posttest design, was a product-oriented, truly experimental research; it focused on the effects of the independent variables (i.e., flipped and non-flipped pedagogy) on the dependent variables (i.e., grammatical competence and writing skill). The study made use of a semi-flipped approach. Moreover, there was no systematic bias in assigning the participants to either the treatment or control group.

\section{Setting and Participants}

This study was conducted at an English language institute in Iran. The participants were 53 basic EFL adult learners who were selected out of 87 students. They had passed four semesters and studied the third edition of the book Top Notch Fundamentals (Saslow \& Ascher, 2015b) and the first half (five units) of Top Notch 1 (Saslow \& Ascher, 2015a). Based on the criterion of the institute, the learners whose final exam scores range between 70 and 100 pass the course. Although the participating students in this study had fulfilled this requirement, their scores ranged between 70 and 80 during the past four semesters. In addition, the instructors stated that these learners experienced difficulty completing written and spoken language tasks as expected from their level of proficiency.

As a result, a total of 53 learners participated in the present study ( 25 female and 28 male). Their ages ranged between 23 and 42 . To ensure the validity of the sampling process, the participants' family names were listed alphabetically and numbered from 1 to 53. The odd numbers (27 learners in total) were assigned to the flipped pedagogy group ( 15 female and 12 male) and the even numbers (26 students) were placed in the non-flipped methodology group (10 female and 16 male). Before the research started, the flipped learning group were briefed on the type and format of instruction they would receive. Furthermore, they were informed that they would also be participating in a research project. They consented to participate and nobody opted out.

\section{Instruments}

The course was designed to improve the learners' grammatical competence and paragraph writing skill at the level of basic users of English. Both groups utilized the same coursebook, namely Longman Academic Writing Series 1: Sentences to Paragraphs (Butler, 2014) and a pamphlet consisting of the first chapter of Longman Academic Writing Series 2: Paragraphs (Hogue, 2014). They were used because the contents and objectives of them paralleled the researchers' ones. In addition, the mentioned books (as their authors pinpointed on page xii of the books) teach rhetoric 
and sentence structure in a straightforward manner, using a step-by-step approach, appropriate models and various practice types. They also offered a carefully structured approach to guide the learners to produce well-organized paragraphs as expected from basic users of English. They provide the learners with realistic models and clear explanations supported by examples and followed by the extensive practice including solitary work as well as the interactive tasks. In addition to the mentioned books, instructional videos (prepared by using the software Camtasia) were also utilized in which the researchers of this study taught the contents of the stated books to the flipped group.

A pretreatment test was provided to check the students' grammatical competence at the outset. The test was a representative sample of the grammar points covered in the third edition of the book Top Notch Fundamentals (Saslow \& Ascher, 2015b) and the first half (five units) of Top Notch 1 (Saslow \& Ascher, 2015a). After the treatment, at the end of the study, another but parallel test of grammar points was administered to check the students' progress in developing their grammatical competence. The tests were prepared by the researchers of this study. The questions of both tests were either compiled from the exercises of Top Notch Fundamentals and the first half (five units) of Top Notch 1 or adapted from the sample final and review tests provided by the Pearson publisher as the sample tests of the mentioned books. Further, the reliability of the pretreatment and post-treatment tests was estimated using the test-retest method and parallel test method, respectively (Hatch \& Lazaraton, 1991).

In addition, a pretest to evaluate writing skill was administered to check the initial status of all the participants' writing skills. A parallel writing skill posttest was given to both groups to examine the effect of the intervention. In each of the tests, the participants were required to write three paragraphs about different topics. The topics were selected from the coursebook Longman Academic Writing Series 1: Sentences to Paragraphs (Butler, 2014) and a pamphlet consisting of the first chapter of Longman Academic Writing Series 2: Paragraphs (Hogue, 2014). The paragraph writing scoring rubrics used in this study have been taken from Thipatdee (2019) and "were based on both micro and macro aspects" (p. 35) as shown in Table 1. Each paragraph was scored separately out of 10 and the total score of the pre- or posttest was graded out of 30 .

Table 1

Scoring Rubrics for Paragraph Writing (Total Score is 10)

\begin{tabular}{llll}
\hline Micro aspects & Score & Macro aspects \\
\hline $\begin{array}{l}\text { Correct spelling, punctuation, } \\
\text { collocations, and grammar }\end{array}$ & 5 & $\begin{array}{l}\text { Content and organization are coherent } \\
\text { and easy to communicate }\end{array}$ \\
\hline $\begin{array}{l}\text { An error found even on spelling, } \\
\text { punctuations, collocations, and grammars }\end{array}$ & $\begin{array}{l}\text { An error found even on content or } \\
\text { organization }\end{array}$ \\
\hline $\begin{array}{l}\text { Two to three errors found in spelling, } \\
\text { punctuations, collocations, and grammars }\end{array}$ & 3 & $\begin{array}{l}\text { Some (two to three) errors found in } \\
\text { content or organization }\end{array}$ \\
\hline $\begin{array}{l}\text { Four to five errors found in spelling, } \\
\text { punctuations, collocations, and grammars }\end{array}$ & 2 & $\begin{array}{l}\text { Several (four to five) errors found in } \\
\text { content or organization }\end{array}$ \\
\hline More than 5 errors found & 1 & $\begin{array}{l}\text { Content and organization are not } \\
\text { coherent and difficult to communicate }\end{array}$ \\
\hline
\end{tabular}




\section{Data Collection Procedure}

Before the study started, the prepared pre-treatment test of grammatical competence was administered twice (after a lapse of ten days) to the same group of 20 students who were at the same level of proficiency as the participants (Hatch \& Lazaraton, 1991) and subsequently the reliability of the test was estimated running the Pearson correlation. The time lapse of ten days was decided following Henning (1987, as cited in Hatch \& Lazaraton, 1991), which recommended that "the time lapse should be less than two weeks" (p. 532).

After ensuring the reliability of the pre-treatment test of grammatical competence, the 53 learners, who had already been called the low-achievers by the teachers, were assigned randomly to two flipped and non-flipped groups. Then, in the first session of each course, the pretest of grammatical competence was given to both groups. This took about sixty minutes. The participants took a break of 30 minutes, and then the pretest of writing skill was administered, which also took about an hour. The tests were conducted in order to not only ensure the groups were statistically equivalent in terms of their grammatical knowledge and writing skill but also to determine the status of their grammatical knowledge and writing skill before the intervention.

The treatment/intervention lasted for ten sessions. Each course met twice a week for two hours with a ten-minute break time. The Appendix indicates the objectives and contents of each session. Although part of the focus of the coursebook Longman Academic Writing Series is on process writing, it was omitted from this study because the current research was product oriented and also to control the probably limited capacity of learners' attention.

During session 11 (after finishing the treatment sessions), the immediate posttest of grammatical competence was given to both groups, which took about an hour. It should be noted that before administering this test, its reliability was calculated using the parallel test method (Hatch \& Lazaraton, 1991). The pretest and the posttest of grammatical knowledge were given to the same group of 18 students at the same time. These learners were at the same level of proficiency as the participants. Finally, the reliability of the posttest was estimated running the Pearson correlation. When the posttest of grammatical knowledge was finished, the learners took a 30-minute break; then, the posttest of writing skill was administered, which also took about an hour.

\section{Procedure in the non-flipped classroom}

In the non-flipped group, the teacher lectured on the contents of the chapters of the book and pamphlet. The exercises were mostly done in class; however, most of the class time had to be used for teacher's explaining the lesson; therefore, there was limited time for the writing practice. Consequently, the learners were required to finish the remaining exercises of the book or pamphlet as well as their writing tasks at home. To control the possible effect of written corrective feedback (WCF), the students' written assignments were not corrected by the teacher; nonetheless, the students could ask their questions each session to confirm their knowledge or understanding of the previous session's contents. 


\section{Procedure in the flipped classroom}

The participating pupils in the flipped group, at their convenience, received the prerecorded instructional videos by email or downloaded them to their smart phones, tablets, or laptops in class. Then, they were required to watch the video lectures or study the coursebook and do the exercises before class, and in class, the learners had the opportunity to ask questions about video content, evaluate and confirm their understanding based on the preclass input content. Due to the fact that the students were basic users of English, the likelihood of non- or mis-understanding to occur due to insufficient English ability was high, so in the classroom, the students were sometimes required at random to lecture on what they had learned from the video. Peer- and groupwork activities or discussion was also done to clarify any confusion or misunderstanding. As for the writing tasks, the learners could write collaboratively and receive the teachers' guidance while writing. Like the non-flipped group, in the flipped group the students' written assignments were not corrected by the teacher in order to control the possible effect of the WCF.

\section{FINDINGS}

\section{Estimating the Reliability}

According to Hatch and Lazaraton (1991), the pretest and posttest of grammatical knowledge had good reliability, as the Cronbach alpha coefficient reported .96 and .97, respectively. Furthermore, the Cronbach alpha indices, administered to calculate the inter-rater reliability of the pre- and posttest of writing, reveal a range from a low of .96 to a high of .99 .

\section{The Normality Tests}

The assumption of normality was examined through both the graphic of the histogram, and also some numerical ways as recommended by Larson-Hall (2010). Regarding the numerical methods of assessing normality, two measures were considered: (1) the values of skewness and kurtosis statistics, which must be within $+/-1$, based on Phakiti (2010), and (2) the outcomes of the ratio of skewedness and kurtosis over their respective standard errors, which must fall within the ranges of $+/-1.96$, based on Field (2013). In this study, all the tests proved to be normally distributed.

\section{Ensuring the Homogeneity of the Groups}

An independent t-test was conducted to compare the pretest of grammatical knowledge scores for the flipped and non-flipped groups. The assumption of homogeneity of variances was met (Levene's $\mathrm{F}=.13, \mathrm{p}=.71$ ). There was no significant difference in scores for flipped $(\mathrm{M}=72.22, \mathrm{SD}=2.43)$ and non-flipped $(\mathrm{M}=72.69, \mathrm{SD}=2.52)$; $(\mathrm{t}$ $(51)=-.68, \mathrm{p}=.49)$. The magnitude of the differences in the means (mean differences $=$ $-.47,95 \%$ CI: -1.83 to .89 ) is very small (eta squared $=.00$ ), based on Cohen, 1988 , as cited in Pallant, 2013).

Then, another independent t-test was conducted to compare the pretest of writing scores for the flipped and non-flipped groups. The assumption of homogeneity of variances 
was violated (Levene's $\mathrm{F}=.03, \mathrm{p}=.85$ ). Based on the second row of t-test table, labeled "Equal variances not assumed", there is no significant difference in scores for flipped $(\mathrm{M}=10.64, \mathrm{SD}=2.50)$ and non-flipped $(\mathrm{M}=10.42, \mathrm{SD}=2.45) ;(\mathrm{t}(51)=.33, \mathrm{p}=.74)$. The magnitude of the differences in the means (mean differences $=.22,95 \%$ CI: -1.14 to 1.59 ) is very small (eta squared $=.00$ ), based on Cohen, 1988, as cited in Pallant, 2013).

\section{Finding of the First Research Question}

The first research question explored whether there is any significant difference between the flipped and non-flipped groups in their paragraph writing skill after the treatment. An independent t-test was conducted to compare the posttest of writing skill scores for the flipped and non-flipped groups. The assumption of homogeneity of variances was met (Levene's $\mathrm{F}=.21, \mathrm{p}=.64)$. There is a significant difference in scores for flipped ( $\mathrm{M}$ $=25.27, \mathrm{SD}=2.77)$ and non-flipped $(\mathrm{M}=22.21, \mathrm{SD}=2.53) ;(\mathrm{t}(51)=4.19, \mathrm{p}=.000)$. However, the magnitude of the differences in the means (mean differences $=3.06,95 \%$ CI: 1.60 to 4.53 ) is small (eta squared $=.2$ ), based on Cohen, 1988 , as cited in Pallant, 2013).

\section{Finding of the Second Research Question}

The second research question investigated whether there is any significant difference between the flipped and non-flipped groups in their grammatical competence after the treatment. An independent t-test was conducted to compare the pretest of grammatical knowledge scores for the flipped and non-flipped groups. The assumption of homogeneity of variances was met (Levene's $\mathrm{F}=.34, \mathrm{p}=.55>.05$ ). There is a significant difference in scores for flipped $(\mathrm{M}=94.07, \mathrm{SD}=1.94)$ and non-flipped $(\mathrm{M}=$ 84.19, $\mathrm{SD}=2.22) ;(\mathrm{t}(51)=17.24, \mathrm{p}=.000)$. The magnitude of the differences in the means (mean differences $=9.88,95 \%$ CI: 8.73 to 11.03 ) is very large (eta squared $=$ 1.21), based on Cohen, 1988, as cited in Pallant, 2013).

\section{Finding of the Third Research Question}

The third research question investigated whether the non-flipped intervention caused any significant change in the participants' grammatical competence. A paired-samples ttest was conducted to evaluate the impact of the intervention on the score the students attained in the grammatical knowledge test. There was a statistically significant increase in the grammatical knowledge test from pre-intervention $(\mathrm{M}=72.45, \mathrm{SD}=2.47)$ to post-intervention $(\mathrm{M}=89.23, \mathrm{SD}=5.39), \mathrm{t}(52)=-23.22, \mathrm{p}=.000<.05$. The mean increase in scores was -16.77 with a $95 \%$ confidence interval ranging from -18.22 to 15.32. The eta squared statistics (.95) indicate a very large effect size.

\section{Finding of the Fourth Research Question}

The fourth question explored whether the non-flipped intervention caused any significant change in the writing skill of the non-flipped participants. A paired-samples t-test was conducted to evaluate the impact of the intervention on students' writing skill. There was a statistically significant increase in the quality of the non-flipped participants' writing skill from pre-intervention $(\mathrm{M}=10.42, \mathrm{SD}=2.45)$ to post- 
intervention $(\mathrm{M}=22.21, \mathrm{SD}=2.53), \mathrm{t}(25)=-186.87, \mathrm{p}=.000<.05$. The mean increase in scores was -11.78 with a $95 \%$ confidence interval ranging from -11.91 to 11.65. The eta squared statistics (.88) indicate a very large effect size.

\section{DISCUSSION}

This study investigated the impact of the flipped instruction on Iranian EFL students' development of grammatical competence and writing skill. The participants consist of basic users of English although they were considered as low-achievers based on their test scores, the opinions of their instructors, and CEFR. Despite the fact that based on the findings of the $3^{\text {rd }}$ and $4^{\text {th }}$ questions, the conventional non-flipped lecture-based instruction proved to be significantly effective, which was expected as the method has been used worldwide for decades, the findings of the $1^{\text {st }}$ and $2^{\text {nd }}$ research questions prove that the flipped learning approach improves learners' grammatical knowledge and paragraph writing skill more than the conventional non-flipped lecture-based instruction, so adopting flipped pedagogy in grammar and writing classes may be considered as an effective methodology. The findings support the previous relevant studies concerning the impact of flipped instruction on the EFL students' English learning, especially in terms of writing ability (Afrilyasanti et al., 2016; Ahmed, 2016; Ekmekci, 2017; Farah, 2014; Hung, 2015; G. Lee \& Wallace, 2018; Leis et al., 2015; Soltanpour \& Valizadeh, 2018).

Several factors are inherent in the flipped pedagogy, which contribute to its effectiveness over the conventional non-flipped instruction. Firstly, it should be reiterated that flipped instruction is consistent with Vygotsky's socio-cultural learning theory (Richards \& Rodgers, 2014) and Long's (1996) Interaction Hypothesis, both of which entail a learner-centered learning environment in which knowledge and understanding are socially constructed through teacher-learner interaction and face-toface negotiation (Nyikos \& Hashimoto, 1997; O’Donoghue \& Clarke, 2010; Woo \& Reeves, 2007; Xu \& Shi, 2018). The effectiveness of such interaction had already been proved and thus it has been highly recommended (Han \& Hyland, 2015; Hyland, 2009; I. Lee, 2013; Lin \& Yang, 2011; Nassaji, 2011; Nicol, 2010; Pica, 1994; Soltanpour \& Valizadeh, 2018; Williams \& Severino, 2004). In brief, it is highly likely that through the process of negotiation in flipped methodology during the flipped course, the participants were able to discover their own strengths and weaknesses; they could also learn what to "do to close the gaps (i.e. improve the weaknesses) in their writing" (I. Lee, 2014, p. 204).

The next factor in flipped instruction, which is also an aspect of social constructivism and could have a principal role in the effectiveness of the flipped instruction, is that the learners are actively engaged in and undertake responsibility for their own learning, which has already been proved to be an essential factor in learning (Baepler et al., 2014; Basal, 2015; Davies et al., 2013; Muldrow, 2013; O'Flaherty \& Phillips, 2015; Soltanpour \& Valizadeh, 2018; Xu \& Shi, 2018). As a matter of fact, students actively construct their knowledge; they are not "passive recipients of external stimuli; and the teacher is the facilitator of the instructional process" (Xu \& Shi, 2018, p. 880). Furthermore, the opportunity of collaborative writing could have positive effects on the 
participants' writing ability, which was also proved in several previous studies (Ajideh, Leitner, \& Yazdi-Amirkhiz, 2016; Elola \& Oskoz, 2010; Shehadeh, 2011; Storch, 2005; Storch \& Wigglesworth, 2007). The collaborative writing has also been emphasized by the sociocultural perspective in second language pedagogy (Cumming, 2001) because it requires learners to reflect on their language-related problems while doing their writing tasks (Swain, 2000) and as a result of the interaction inherent in collaborative work, their knowledge will be co-constructed (Storch, 2005).

Finally, as for the semi-flipped pedagogy, the instructional videos, with the possibility of being reviewed by the individuals at their own pace and as many times as needed provide an instructional setting more in tune with the individual differences, such as their different learning styles and needs (Afrilyasanti et al., 2016; Cohen, 2012; Dörnyei, 2005; Mayer \& Moreno, 2003; Soltanpour \& Valizadeh, 2018).

\section{CONCLUSION}

Based on the findings of this study and the discussed points, it can be understood that through the flipped pedagogy, (1) both cognitive apprenticeship and scaffolding happened, (2) the learners were involved in reflective thinking (Nyikos \& Hashimoto, 1997), (3) the accountability for learning was primarily on the learner, but the teacher, also as the more knowledgeable person, was responsible for providing support to facilitate the process of learning because as Benko (2012) and Milman (2012) stated, scaffolding is crucial for tasks which students cannot accomplish independently due to their lack of language abilities. Additionally, flipped instruction helped the learners restructure their interlanguage through various functions of interactional modifications; in other words, learners were provided with a condition to receive comprehensible input, produce modified output, and notice the gaps in their knowledge (Mackey, 2012). As a result, they understood what to "do to close the gaps (i.e. improve the weaknesses) in their writing" (I. Lee, 2014, p. 204).

In brief, although the process of implementing the flipped instruction was challenging, the experience was rewarding for us as teacher-researchers. The teachers who have already experienced the flipped pedagogy also expressed their satisfaction with this kind of instruction. For example, teachers in Ansori and Nafi (2019) stated that flipped instruction can facilitate active learning, develop collaborative teamwork, stimulate autonomous learning, and increase classroom interaction. Therefore, EFL teachers are highly recommended to implement the flipped instruction in their classes. However, there is no denying that the flipped pedagogy can also be overwhelming because (a) it needs some supporting facilities, (b) teachers may encounter some technical and technological problems, (c) creating flipped learning materials can be challenging for the teachers, and (d) students are mostly unaccustomed to this technique and convincing them to apply this technique can be burdensome in some cultures.

\section{DELIMITATIONS AND SUGGESTIONS}

The researchers wish to explore two more points, yet such investigation was not possible because the participants did not grant their consent. First, it was really important to run the delayed-posttest to explore the stability of the positive effects of the intervention or 
the superiority of the flipped instruction. Second, in order to consider the participants' attitudinal engagement (Ellis, 2010) (i.e., their attitudes towards and expectations of the value of the flipped instruction) as well as discovering their individual differences via analyzing their comments (Hyland, 2009), a qualitative study was needed; despite this, most of the participants did not consent to giving interviews. In both cases, the participants offered lack of sufficient free time as their excuses for not sitting the delayed-posttest and not giving interviews. To sum up, it is highly recommended that future researchers consider these two points in their similar projects.

\section{REFERENCES}

Afrilyasanti, R., Cahyono, B. Y., \& Astuti, U. P. (2016). Effect of flipped classroom model on Indonesian EFL students' writing ability across and individual differences in learning. International Journal of English Language and Linguistics Research, 4(5), $65-81$.

Ahmed, M. A. E. A. S. (2016). The effect of a flipping classroom on writing skill in English as a foreign language and students' attitude towards flipping. US-China Foreign Language, 14(2), 98-114. https://doi.org/10.17265/1539-8080/2016.02.003.

Ajideh, P., Leitner, G., \& Yazdi-Amirkhiz, S. Y. (2016). The influence of collaboration on individual writing quality: The case of Iranian vs. Malaysian college students. Journal of English Language Teaching and Learning, 17, 1-24.

Ansori, M., \& Nafi, N. N. (2019). English teachers' perceived benefits and challenges of flipped classroom implementation. JEELS (Journal of English Education and Linguistics Studies), 5(2), 211-228. https://doi.org/10.30762/jeels.v5i2.820.

Baepler, P., Walker, J. D., \& Driessen, M. (2014). It's not about seat time: Blending, flipping, and efficiency in active learning classrooms. Computers \& Education, 78, $227-$ 236. https://doi.org/10.1016/j.compedu.2014.06.006.

Basal, A. (2015). The implementation of a flipped classroom in foreign language teaching. Turkish Online Journal of Distance Education, 16(4), 28-37. https://doi.org/10.17718/tojde.72185.

Benko, S. L. (2012). Scaffolding: An ongoing process to support adolescent writing development. Journal of Adolescent \& Adult Literacy, 56(4), 291-300. https://doi.org/10.1002/JAAL.00142.

Bishop, J. L., \& Verleger, M. A. (2013). The flipped classroom: A survey of the research. In 120th ASEE Annual Conference \& Exposition in Atlanta.

Bonnell, C. C., \& Eison, J. A. (1991). Active learning: Creating excitement in the classroom. Washington, DC: George Washington University Press.

Butler, L. (2014). Longman academic writing series 1: Sentences to paragraphs. New York, NY: Pearson Education, Inc.

Cohen, A. D. (2012). Strategies: The interface of styles, strategies, and motivation on 
tasks. In S. Mercer, R. Stephen, \& M. Williams (Eds.), Psychology for language learning: Insights from research, theory and practice (pp. 136-150). Basingstoke, England: Palgrave Macmillan.

Cumming, A. (2001). Learning to write in a second language: Two decades of research. IJES, International Journal of English Studies, 1(2), 1-23.

Danker, B. (2015). Using flipped classroom approach to explore deep learning in large classrooms. The IAFOR Journal of Education, 3(1), 171-186.

Davies, R. S., Dean, D. L., \& Ball, N. (2013). Flipping the classroom and instructional technology integration in a college-level information systems spreadsheet course. Educational Technology Research and Development, 61(4), 563-580. https://doi.org/10.1007/s11423-013-9305-6.

Dörnyei, Z. (2005). The psychology of the language learner: Individual differences in second language acquisition. Mahwah, NJ: Lawrence Erlbaum.

Egbert, J., Herman, D., \& Lee, H. (2015). Flipped instruction in English language teacher education: A design-based study in a complex, open-ended learning environment. TESL-EJ, 19(2), 1-23.

Ekmekci, E. (2017). The flipped writing classroom in Turkish EFL context: A comparative study on a new model. Turkish Online Journal Of Distance Education (Tojde), 18(2), 151-167. https://doi.org/10.17718/tojde.306566.

Ellis, R. (2010). EPILOGUE: A framework for investigating oral and written corrective feedback. Studies in Second Language Acquisition, 32(02), 335-349. https://doi.org/10.1017/S0272263109990544.

Elola, I., \& Oskoz, A. (2010). Collaborative writing: Fostering foreign language and writing conventions development. Language Learning \& Technology, 14(3), 51-71.

Farah, M. (2014). The impact of using flipped classroom instruction on the writing performance of twelfth grade female Emirati students in the applied technology high school (ATHS) (Unpublished master thesis). The British University in Dubai (BUiD). Retrieved from https://bspace.buid.ac.ae/bitstream/1234/676/1/120088.pdf

Field, A. (2013). Discovering statistics using SPSS. London: Sage.

Han, Y., \& Hyland, F. (2015). Exploring learner engagement with written corrective feedback in a Chinese tertiary EFL classroom. Journal of Second Language Writing, 30, 31-44. https://doi.org/10.1016/j.jslw.2015.08.002.

Hatch, E., \& Lazaraton, A. (1991). The research manual: Design and statistics for applied linguistics. Boston, US: Heinle \& Heinle.

Hogue, A. (2014). Longman academic writing series 2: Paragraphs. New York, NY: Pearson Education, Inc.

Hung, H.-T. (2015). Flipping the classroom for English language learners to foster 
active learning. Computer Assisted Language Learning, 28(1), 81-96. https://doi.org/10.1080/09588221.2014.967701.

Hyland, K. (2009). Teaching and researching writing. Harlow, UK: Pearson Education Limited.

Johnson, L. W., \& Renner, J. D. (2012). Effect of the flipped classroom model on a secondary computer applications course: Student and teacher perceptions, questions and student achievement. (Unpublished doctoral dissertation). University of Louisville. Louisville, Kentucky. $\quad$ Retrieved from https://s3.amazonaws.com/academia.edu.documents/38862495/Flipped_Classroom.pdf? AWSAccessKeyId=AKIAIWOWYYGZ2Y53UL3A\&Expires $=1510424082 \&$ Signature $=$ XOVPml8uXfHMhVMnN3n9e3N95cU\%3D\&response-contentdisposition=inline\%3B filename\%3DEffects_of_Flipped_Classroom.p.

Larson-Hall, J. (2010). A guide to doing statistics in second language research using SPSS. New York, NY: Routledge.

Lee, G., \& Wallace, A. (2018). Flipped learning in the English as a foreign language classroom: Outcomes and perceptions. TESOL Quarterly, 52(1), 62-84. https://doi.org/10.1002/tesq.372.

Lee, I. (2013). Second language writing: Perspectives of a teacher educator-researcher. Journal of Second Language Writing, 22(4), 435-437. https://doi.org/10.1016/j.jslw.2013.08.005.

Lee, I. (2014). Revisiting teacher feedback in EFL writing from sociocultural perspectives. TESOL Quarterly, 48(1), 201-213. https://doi.org/10.1002/tesq.153.

Leis, A., Tohei, A. A., \& Cooke, S. (2015). The effects of flipped classrooms on English composition writing in an EFL environment. International Journal of ComputerAssisted Language Learning and Teaching (IJCALLT), 5(4), 37-51. https://doi.org/10.4018/IJCALLT.2015100103.

Lin, W. C., \& Yang, S. C. (2011). Exploring students' perceptions of integrating Wiki technology and peer feedback into English writing courses. English Teaching: Practice and Critique, 10(2), 88-103.

Long, M. H. (1996). The role of the linguistic environment in second language acquisition. In W. C. Ritchie, \& T. K. Bhatia (Eds.), Handbook of second language acquisition (pp. 438-468). San Diego, CA: Academic Press.

Mackey, A. (2012). Input, interaction, and corrective feedback in L2 learning. Oxford, UK: Oxford University Press.

Mayer, R. E., \& Moreno, R. (2003). Nine ways to reduce cognitive load in multimedia learning. Educational Psychologist, $38(1), \quad$ 43-52. https://doi.org/10.1207/S15326985EP3801_6.

Meyers, C., \& Jones, T. B. (1993). Promoting active learning: Strategies for the college 
classroom. San Francisco, CA: Jossey-Bass.

Milman, N. B. (2012). The flipped classroom strategy. Distance Learning, 9(3), 85-88.

Muldrow, K. (2013). A new approach to language instruction: Flipping the classroom. The Language Educator, (November), 28-31.

Nassaji, H. (2011). Correcting students' written grammatical errors: The effects of negotiated versus nonnegotiated feedback. Studies in Second Language Learning and Teaching, 1(3), 315-334. https://doi.org/10.14746/ssllt.2011.1.3.2.

Nicol, D. (2010). From monologue to dialogue: Improving written feedback processes in mass higher education. Assessment \& Evaluation in Higher Education, 35(5), 501517. https://doi.org/10.1080/02602931003786559.

Nyikos, M., \& Hashimoto, R. (1997). Constructivist theory applied to collaborative learning in teacher education: In search of ZPD. The Modern Language Journal. https://doi.org/10.1111/j.1540-4781.1997.tb05518.x.

O’Donoghue, T., \& Clarke, S. (2010). Leading learning: Process, themes and issues in international contexts. Abingdon, Oxon: Routledge.

O'Flaherty, J., \& Phillips, C. (2015). The use of flipped classrooms in higher education: A scoping review. The Internet and Higher Education, 25, 85-95. https://doi.org/10.1016/j.iheduc.2015.02.002.

Pallant, J. (2013). SPSS survival manual: A step by step guide to data analysis using IBM SPSS. Berkshire, England: Open University Press.

Phakiti, A. (2010). Analysing quantitative data. In B. Paltridge \& A. Phakiti (Eds.), Continuum companion to research methods in applied linguistics (pp. 39-49). New York, NY: Continuum Companions.

Pica, T. (1994). Research on negotiation: What does it reveal about second-language learning conditions, processes, and outcomes? Language Learning, 44(3), 493-527. https://doi.org/10.1111/j.1467-1770.1994.tb01115.x.

Richards, J. C., \& Rodgers, T. S. (2014). Approaches and methods in language teaching (3rd. ed.). Cambridge, UK: Cambridge University Press.

Roehl, A., Reddy, S. L., \& Shannon, G. J. (2013). The flipped classroom: An opportunity to engage millennial students through active learning strategies. Journal of Family and Consumer Sciences, 105(2), 44-49.

Saslow, J., \& Ascher, A. (2015a). Top notch 1. New York, NY: Pearson Education, Inc.

Saslow, J., \& Ascher, A. (2015b). Top notch fundamentals. New York, NY: Pearson Education, Inc.

Shehadeh, A. (2011). Effects and student perceptions of collaborative writing in L2. Journal of Second Language Writing, 20(4), 286-305. https://doi.org/10.1016/j.jslw.2011.05.010. 
Soltanpour, F., \& Valizadeh, M. (2018). A flipped writing classroom: Effects on EFL learners' argumentative essays. Advances in Language and Literary Studies, 9(2), 5-13. https://doi.org/10.7575/aiac.alls.v.9n.2p.5.

Storch, N. (2005). Collaborative writing: Product, process, and students' reflections. Journal of Second Language Writing, 14(3), 153-173. https://doi.org/10.1016/j.jslw.2005.05.002.

Storch, N., \& Wigglesworth, G. (2007). Writing tasks: The effects of collaboration. In M. D. P. G. Mayo (Ed.), Investigating tasks in formal language learning (pp. 157-177). London, UK.: Multilingual Matters.

Swain, M. (2000). The output hypothesis and beyond: Mediating acquisition through collaborative dialogue. In J. P. Lantolf (Ed.), Sociocultural theory and second language learning (pp. 97-114). Oxford, UK: Oxford University Press.

Thipatdee, G. (2019). The development of English writing skills through techniques of sentence skeleton and signpost word analysis for English major students. English Language Teaching, 12(4), 32-38. https://doi.org/10.5539/elt.v12n4p32.

Tucker, B. (2012). The flipped classroom: Online instruction at home frees class time for learning. Education Next, 12(1), 82-83.

Williams, J., \& Severino, C. (2004). The writing center and second language writers. Journal of Second Language Writing, 13(3), 165-172. https://doi.org/10.1016/j.jslw.2004.04.010.

Woo, Y., \& Reeves, T. C. (2007). Meaningful interaction in web-based learning: A social constructivist interpretation. Internet and Higher Education, 10(1), 15-25. https://doi.org/10.1016/j.iheduc.2006.10.005.

$\mathrm{Xu}, \mathrm{Z}$. , \& Shi, Y. (2018). Application of constructivist theory in flipped classroom: Take college English teaching as a case study. Theory and Practice in Language Studies, 8(7), 880-887. https://doi.org/10.1007/s10888-007-9063-y. 


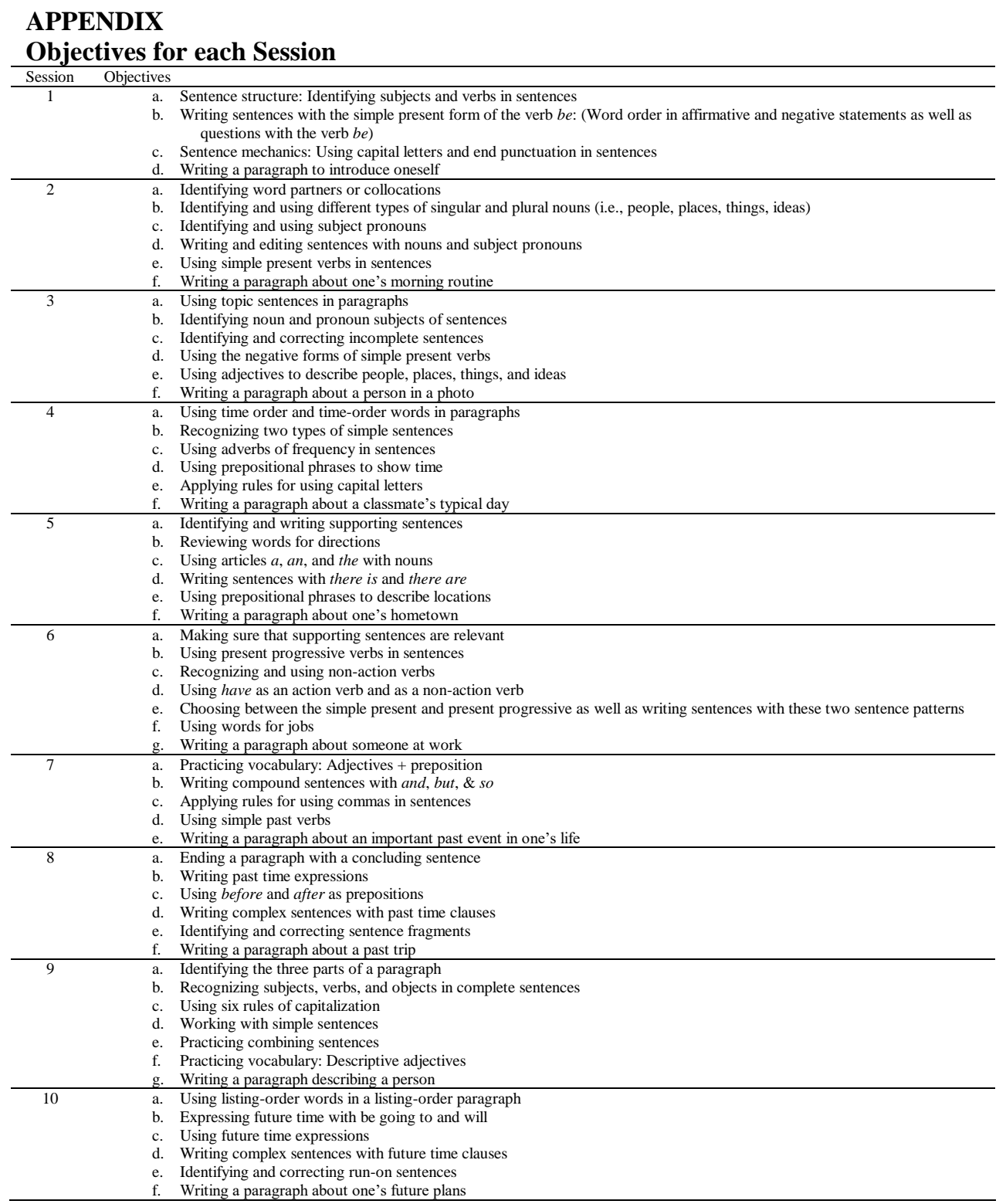

International Journal of Instruction, July $2020 \bullet$ Vol.13, No.3 